\title{
Evaluation of spinal somatosensory evoked potentials in cats with traumatic spinal cord injury without deep pain perception
}

\author{
Oytun Okan ŞENEL ${ }^{1}$, Yusuf Sinan ŞİRİN ${ }^{2}$, Taylan ÖNYAY ${ }^{1}$, Ömer BEŞALTI ${ }^{1}$ \\ ${ }^{1}$ Department of Surgery, Faculty of Veterinary Medicine, Ankara University, ${ }^{2}$ Department of Surgery, Faculty of Veterinary \\ Medicine, Mehmet Akif Ersoy University, Turkey.
}

Summary: The purpose of this study is to present tibial somatosensory evoked potential findings in 25 cats that naturally acquired traumatic spinal cord injury between T9-L4 vertebrae. Cats without deep pain perception after spinal trauma were included. The potentials recorded from scalp, and one spinal segment caudal and one rostral to the injured site were evaluated as normal, incomplete injury potentials, complete injury potentials, major deformation and isoelectric line. Somatosensory evoked potentials could not be recorded from scalp except for one case in which the latency was $12.4 \mathrm{~ms}$. In caudal area of trauma, normal potentials $(n=9)$, incomplete injury potentials $(n=6)$, complete injury potentials $(n=4)$, major deformation $(n=3)$, isoelectric line $(n=3)$ were seen. In rostral area of trauma, incomplete injury $(n=1)$ and complete injury potentials $(n=2)$, isoelectric line $(n=18)$, major deformation $(n=3)$ were seen. In conclusion, rostral part of injured site had more extensive signs of damage which was represented by the isoelectric line, complete injury potentials or major deformation in trace morphology than the caudal area, though caudal area of the injured site was also affected in many cases. The somatosensory evoked and spinal cord evoked potentials can be used as an ancillary diagnostic tool for determination of functional integrity of the ascending tracts of the spinal cord in cats.

Key words: Cat, evoked potentials, spinal cord, trauma.

\section{Derin ağrı duyumu olmayan spinal kord travmalı kedilerde somatosensoriyel uyandırılmış potansiyellerin değerlendirilmesi}

Özet: $\mathrm{Bu}$ çalışmada; T9-L4'üncü vertebraları arasında travmatik spinal kord yaralanması bulunan 25 adet kedinin tibial somatosensoriyel uyandırılmış potansiyel bulgularının sunulması amaçlandı. Çalışmaya; spinal travma sonrasında derin ağrı duyumu olmayan olgular dahil edildi. Travma alan bölgenin bir segment kaudal ve kranialinden kaydedilen ve kafa derisinden alınan kayıtlar değerlendirildi. Kaudal ve kranial bölgeden elde edilen potansiyeller; normal, tam ya da tam olmayan hasar potansiyeli açısından değerlendirildi. Ayrıca elde edilen potansiyeller normal, minör deformasyon, major deformasyon ve izoelektrik çizgi şeklinde de sınıflandırıldı. Bu çalışmada; 12,4 m/s olarak ölçülen bir tanesi dışında, somatosensoriyel uyandırılmış potansiyeller kafa derisinden kaydedilemedi. Travmanın kaudalinde normal potansiyeller $(\mathrm{n}=9)$, tam olmayan hasar potansiyelleri $(\mathrm{n}=6)$, tam hasar potansiyelleri $(n=4)$, major deformasyon $(n=3)$ ve izoelektrik çizgi $(n=3)$ gözlendi. Travmanın rostralinde ise tam olmayan hasar potansiyelleri $(n=1)$, tam hasar potansiyelleri $(n=2)$, major deformasyon $(n=3)$ ve izoelektrik çizgi $(n=18)$ izlendi. Bu çalışmada, somatosensoriyel ve spinal kord uyandırılmış potansiyellerinin kedilerde spinal kordun assendens yollarının fonksiyonel bütünlüğünün belirlenmesine yardımcı bir tanı yöntemi olduğu sonucuna varıldı.

Anahtar sözcükler: Kedi, spinal kord, travma, uyandırılmış potansiyel

\section{Introduction}

Assessment of spinal cord pathology following trauma has been studied in dogs and cats, and some laboratory animals for experimental studies $(3,4,5,6$, 22). Even though technical improvement in enhanced imaging techniques for diagnosing spinal cord pathology, neurological examination is necessary for both diagnosis and assessment of prognosis $(7,14,19,27)$. Although it may sometimes yield equivocal results (24), somatosensory evoked potentials provide objective and noninvasive electrophysiological technique to measure neurological function (6). This technique is suggested as a part or extension of clinical examination by some authors $(3,5)$. The somatosensory-evoked potentials are also useful in diagnostic aid to assess the severity of spinal cord compressions and brachial plexus disorders, and to monitor sciatic nerve function during hip and cauda equina surgery as well as spinal cord function during aortic surgery $(2,11,12,26)$.

Somatosensory evoked potentials is the electrical response of the nervous system produced by activation of a peripheral nerve, and consists of a series of peaks or waves, which are characterized by their polarity, latency and amplitude, and represent purely afferent event $(5,6)$. 
The characteristic features of the SEP are a large negative wave (it also called main negative potential MNP), which often contains 1 or 2 smaller sub-peaks, and a long latency. The MNP represents dorsal horn interneuron depolarization. The MNP followed with a last observed prolonged positive wave which is a stationary current source and a field potential represents primary afferent depolarization in the stimulated segment and its dorsal nerve root $(5,9,16,17)$.

The latency of peaks, amplitude of main negative wave, conduction velocity and central conduction time are the parameters of SEP in both clinical and experimental studies in animals $(3,10,23)$. Trace's morphology was studied in experimentally induced spinal cord injury in cats and rats $(1,21,28)$, in clinical cases in dogs (15).

To our knowledge, this is the first report in clinical cases of spinal cord injury in cats. Previous research from our clinic together with the research of others furnish that the parameter used in the evaluation of SEP are not reliable to measure every time. From this background we have modified a scala from Zileli (28) and Schramm (21)'s studies and adapt it to the clinical cases with spinal cord injury.

\section{Materials and Methods}

Medical records for cats that had paraplegia with loss of both bladder control and deep pain perception, and naturally acquired traumatic spinal cord injury between T9-L4 vertebrae were reviewed between July 2002 and May 2009. Breed, age, sex, etiology were recorded for each cat.

Premedication with atropine sulphate $(0.02 \mathrm{mg} / \mathrm{kg}$, SC) and xylazine hydrochloride (2 $\mathrm{mg} / \mathrm{kg}$, IM) was followed by anesthesia with ketamine hydrochloride (10 $\mathrm{mg} / \mathrm{kg}, \quad \mathrm{IM})$ as a single injection. The cats were positioned in left lateral recumbency and their rectal temperatures were monitored at regular intervals.

Eighteen $\mathrm{mm}$. stainless steel disposable monopolar needle electrodes with a diameter of $0.3 \mathrm{~mm}$, and length of $12 \mathrm{~mm}$ were used for all recordings and stimulations. The recording electrodes were attached to a 5-channel EMG/EP device (Medelec Synergy, Oxford). The filters for recordings were $3 \mathrm{~Hz}$ (-6dB/octave) - $3 \mathrm{KHz}$ ($12 \mathrm{~dB} /$ octave) with a sweep duration of $30 \mathrm{~ms}$.

Stimulation method: The cathode was inserted to a depth of 5-7 $\mathrm{mm}$ at the popliteal fossa close to the right tibial nerve and the anode was positioned subcutaneously about $2 \mathrm{~cm}$ cranial to the cathode. Stimulus strength was kept at a level that induced plantar flexion of the paw and enabled recording of a marked compound muscle action potential in the corresponding gastrocnemius muscle. Testing was performed to ensure that the impedance for the recording electrodes was lower than $2 \mathrm{k} \Omega$ before the start of each of the recording procedures. Rectangular electrical pulses lasting $0.2 \mathrm{~ms}$ were delivered to the tibial nerve. The stimulus intensity applied in order to produce visible flexion.

Table 1: Case details for somatosensory evoked potentials

Tablo 1: Somatosensoriyel uyandırılmış potansiyellerin olgulara göre ayrıntıları

\begin{tabular}{|c|c|c|c|c|c|c|}
\hline No & Age & Sex & Lesion location & Caudal & Rostral & Scalp \\
\hline 1 & 6 & $\mathrm{~F}$ & $\mathrm{~T} 11-12$ & incomplete injury & isoelectric line & NA \\
\hline 2 & 16 & $\mathrm{~F}$ & $\mathrm{~T} 10-\mathrm{T} 11$ & incomplete injury & complete injury & $12.4 \mathrm{~ms}$ \\
\hline 3 & 6 & M & T12-13 & incomplete injury & isoelectric line & NA \\
\hline 4 & 4 & M & T9-T10 & complete injury & isoelectric line & NA \\
\hline 5 & 9 & M & $\mathrm{T} 11$ & isoelectric line & isoelectric line & NA \\
\hline 6 & 5 & M & L1-2 & normal potentials & isoelectric line & NA \\
\hline 7 & 3 & $\mathrm{~F}$ & L1-2 & incomplete injury & complete injury & NA \\
\hline 8 & 9 & M & $\mathrm{T} 11$ & isoelectric line & isoelectric line & NA \\
\hline 9 & 5 & M & T12-13 & normal potentials & major deformation & NA \\
\hline 10 & 4 & $\mathrm{~F}$ & $\mathrm{~T} 10-11$ & major deformation & isoelectric line & NA \\
\hline 11 & 3 & M & T13-L1 & isoelectric line & isoelectric line & NA \\
\hline 12 & 3 & M & L1-L2 & incomplete injury & incomplete injury & NA \\
\hline 13 & 3 & M & L1-2 & complete injury & isoelectric line & NA \\
\hline 14 & 3 & M & L1-L2 & incomplete injury & isoelectric line & NA \\
\hline 15 & 6 & M & $\mathrm{T} 10-\mathrm{T} 11$ & normal potentials & isoelectric line & NA \\
\hline 16 & 9 & M & $\mathrm{T} 11$ & complete injury & major deformation & NA \\
\hline 17 & 5 & M & $\mathrm{T} 12-13$ & major deformation & isoelectric line & NA \\
\hline 18 & 5 & $\mathrm{~F}$ & T13-L1 & complete injury & isoelectric line & NA \\
\hline 19 & 4 & $\mathrm{~F}$ & L1-2 & normal potentials & isoelectric line & NA \\
\hline 20 & 6 & M & L2-L3 & normal potentials & isoelectric line & NA \\
\hline 21 & 6 & $\mathrm{~F}$ & T13-L1 & normal potentials & isoelectric line & NA \\
\hline 22 & 8 & $\mathrm{~F}$ & T10-11 & normal potentials & isoelectric line & NA \\
\hline 23 & 6 & M & $\mathrm{T} 11-12$ & normal potentials & isoelectric line & NA \\
\hline 24 & 9 & M & $\mathrm{T} 12-13$ & major deformation & isoelectric line & NA \\
\hline 25 & 10 & M & $\mathrm{T} 11-12$ & normal potentials & major deformation & NA \\
\hline
\end{tabular}


Recording method: The ground electrode was inserted subcutaneously on the right forelimb. The recording sites and the electrode placements were as follows:

Channel 1: Caudal to the lesion; the recording electrode was placed one segment caudal to the injured site and near the interarcuate ligament between the spinous processes and the reference electrode subcutaneously 1-3 $\mathrm{cm}$ lateral to the recording electrode on the right side.

Channel 2: Rostral to the lesion; the recording electrode was placed one segment rostral to the injured site and near the interarcuate ligament between the spinous processes and the reference electrode subcutaneously $1-3 \mathrm{~cm}$ lateral to the recording electrode on the right side.

Channel 3: Scalp; the recording electrode was placed on the central zero (vertex), and the reference electrode on frontal zero (vertex) (EEG system), subcutaneously.

Approximately 250 responses were recorded and the procedure was repeated at least 2 times in every cat to ensure reproducibility. Traces showing inconsistency were excluded from evaluation. Artifact rejection was configured as $50 \mu \mathrm{v}$ for all canals.

Analysis of Traces: Adjusted potentials were classified into 5 degrees which was modified from Schramm and Zileli $(21,28)$, as shown below:

0 : Isoelectric line,

1: Major deformation or questionable response which is repeatable but not reliable potential,

2: Complete injury potentials: A large positive polarity, no first negative polarity or only small negative peaks, a negative after wave.,

3: Incomplete injury potentials: A more ponounced first positivity which is greater than the first negativity.

4: Normal: Large negative potential starting with positive deflection or initial small triphasic wave which is recorded $42.9 \%$ in the lumbar area and in $26.8 \%$ in the thoracic area (3), and followed with prolonged large positive wave, and contains 1 or 2 smaller sub-peaks (figure I) $(5,8,16)$

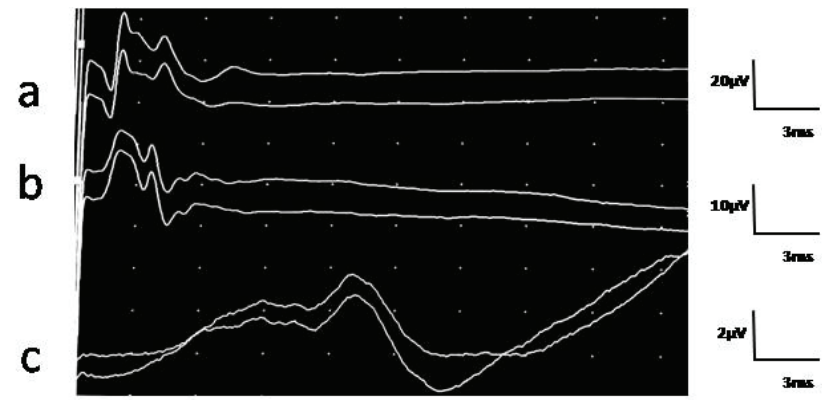

Figure 1. Normal potentials from the lumbar (a), thoracic (b) and scalp area (c) (In a case without history of spinal disorders). Şekil 1. Lumbal (a) ve torasik (b) bölgeler ile kafa derisinin (c) normal potansiyelleri (spinal hasar hikayesi bulunmayan bir olguda).

\section{Results}

Twenty five cats matched the criterias of the study. The breed dispersion was domestic shorthair cats $(n=21)$, Turkish Angora $(n=2)$, Siamese $(n=1)$, Persian $(n=1)$, sex dispersion were 8 female 17 male. The most common cause of the spinal trauma was traffic accidents in 16 cats. In the rest, the cause of the truma was unknown.

Somatosensory evoked potentials were not recorded from scalp (figure 2c, 3c) in any cases except for one case in which the onset latency was $12.4 \mathrm{~ms}$. In caudal area of trauma normal potentials $(n=9)$, incomplete injury potentials $(n=6)$, complete injury potentials $(n=4)$ (Fig. $2 a)$, major deformation $(n=3)$, isoelectric line $(n=3)$ (figure 2c) were seen. In rostral area of trauma, incomplete injury $(\mathrm{n}=1)$ (figure $3 \mathrm{~b}$ ) and complete injury potentials $(n=2)$, isoelectric line $(n=19)$, major deformation $(n=3)$ (figure $3 b)$ were seen.

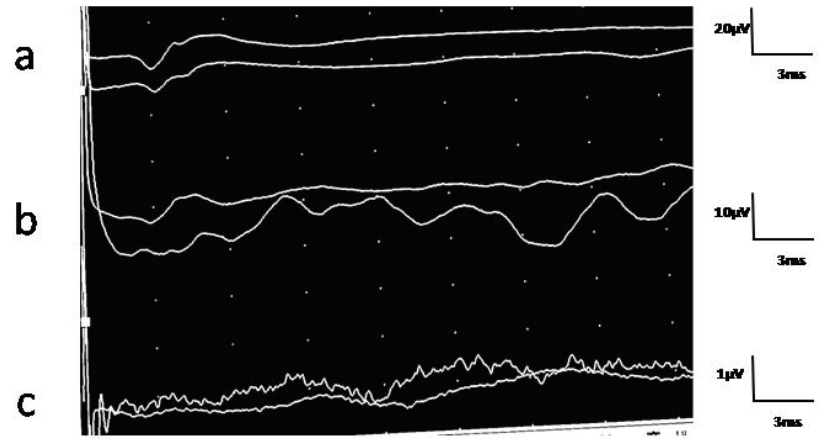

Figure 2. Complete injury potentials in caudal area of trauma (a), major deformation and/or questionable results in rostral area of trauma (b) and isoelectric line at scalp records (c) (Case no16).

Şekil 2. Travmanın kaudalinde tam hasar potansiyelleri (a), travmanın rostralinde major deformasyon ve/veya şüpheli sonuçlar (b), kafa derisinde izoelektrik çizgi (c) (Olgu no 16).

a

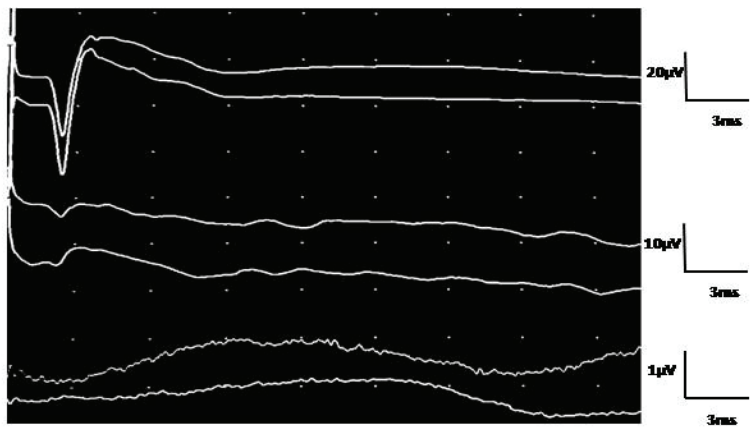

Figure 3. Incomplete injury potentials in caudal area of trauma (a), complete injury potentials in rostral area of trauma (b) and isoelectric line of scalp records (c) (Case no 2).

Şekil 3. Travmanın kaudalinde tam olmayan hasar potansiyelleri (a), travmanin rostralinde tam hasar potansiyeli (b), kafa derisinde izoelektrik çizgi (c) (Olgu no 2). 
The potentials' deformations were in the same severity as isoelectric line in both caudal and rostral site of injury in 3 cases, and incomplete injury in both site in one case. The severities of deformation in the caudal site of injury were less than rostral site of injury in 21 cases.

\section{Discussion and Conclusion}

The potentials deformations were not seen only in rostral site but also in caudal site. The severity of deformation in the caudal site of injury was less than rostral site of injury in 21 cases. However it was in equal number in 4 cases. When the electrophysiological findings of this study was compared to paraplegia without deep pain perception, isoelectric line is prominent $(n=19, \% 76)$ in the rostral site, and this is in accordance regarding to prognosis with the neurolgical examination findings. In addition except for one cases with incomplete injury the rest five cases had also major deformation or complete injury potentials.

The tibial SEPs have been used to evaluate the function of the ipsilateral dorsal spinocerebellar tract and the contra-lateral ventrolateral tracts with respect to the side of the stimulated limb (17). Ascending volley is recorded at the rostral to the lumbar intumescence in which cord dorsum potentials is recorded prominently (16). The trace morphology in healthy cats was analyzed in our previous study (3), and it was also represented in some other report (18).

There was some default in evaluation of SEP: The Onset MNP was not clear enough to mark or to measure. In cases the potentials recorded near to the lumbar intumescence an initial small triphasic wave was recognized, this also made difficult to measure onset latency. The numbers of waveforms observed in the lumbar and thoracic potentials were also reported differently $(3,18)$. The end point of the last waveform of the potential was not highlighted by authors $(9,16)$, but it is unclear.

The lumbar potential amplitudes are higher than the thoracic potentials (16) and decreasing greater than 50\% in the amplitude is diagnostic of irreversible changes in the spinal cord during aortic surgery or in some spinal cord disorders $(4,10,25)$. In our previous study, the amplitude at T12 - T13 was higher than that reported by Redding et al. (18) (in which measuring method is not clear), and lower than found by Nordwall et al. (13) who recorded the potentials from the cancellous bone of the spinous processes. In the present study, we found that the SEP's amplitudes are different from Redding et al and Nordwall et al $(13,18)$, and they are too variable to be useful in the assessment of the functional state of the spinal cord.

In a number of studies on latency, a relatively large range of values have been reported, for examination of spinal cord conduction $(9,16,17)$. There is still no consensus in the literature on the determination of diagnosis or prognosis based on latency. It was showed that the amplitude and latencies were quite stable before injury in a rat model with epidural recording method used in the study (23). In contrast to this study, major deformation, development of evoked injury potentials and complete potential lost in cat with experimentally induced severe spinal cord injury in which epidural recording method was reported (28). In clinical cases epidural recording is not feasible, and less invasive methods are preferred $(5,8,13,16,17,18,20,24)$.

Commonly, the spinal cord evoked injury potentials is known to represent the action potentials ascending the cord tracts up to the site of injury but not passing it (21). Spinal cord injury or compression will partially or completely block the ascending evoked potentials (AEP) of the spinal cord (i.e. potentials evoked by stimulation of peripheral nerves and recorded from electrodes placed adjacent to the spine). Electrodes placed near the lesion will record potentials that have the same shape as positive sharp waves in muscle fibers, differing only in time course and amplitude (9). Spinal cord evoked injury potentials can be used for determining the injury level and the amount of severity $(9,28)$.

Alterations in spinal evoked potentials caudal to the lesion has been reported in two of nine spinal cord transected experimental study in which evoked injury potentials recorded a few millimeters caudal to the injury site (21). This finding was explained by intramedullary hemorrhagic necrosis or hematoma. In this case series evoked injury potentials were seen in caudal site in 14 cases (\%36). This disagreement can be related with the case subjected in this study had a history of spinal cord injury for 1-7 days, and relatively chronic, in which secondary injury or glial reaction can be expected.

In conclusion we classified the trace morphology at both caudal and rostral site of injured spinal cord. In case the normal potentials couldn't be recorded, latency, amplitude, central conduction time and central conduction velocity could not also be evaluated. In this situation scoring system employed in this study can be suggested as a clinically reliable method.

\section{References}

1. Agrawal G, Sherman D, Thakor N, All A (2008): $A$ Nowel Shape Analysis Technique for Somatosensory evoked Potentials. 30th Annual International IEEE EMBS Conference, Vancouver, British Columbia, Canada, August 20-24.

2. Bailey CS (1984): Patterns of Cutaneous Anesthesia Associated with Brachial Plexus Avulsion in the Dog. Journal of American Veterinary Medical Association, 185: 889-899.

3. Besalti O, Ozak A, Senel OO, Eminaga S, Gokce AP, Sener HO (2007): Scalp and Thoracolumbar Recorded 
Somatosensory Potentials Evoked by Tibial Nerve Stimulation in Cats. Vet Neurol Neurosurg J. 9:1.

4. Cracco RQ, Evans B (1978): Spinal Evoked Potential in the Cat: Effects of Asphyxia, Strychnine, Cord Section and Compression. Electroencephalography and Clinical Neurophysiology, 44: 187-201.

5. Cuddon PA, Delauche AJ, Hutchison JM (1999): Assessment of dorsal nerve root and spinal cord dorsal horn function in clinically normal dogs by determination of cord dorsal potentials. American Journal of Veterinary Research, 60: 222-226.

6. Hayton SM, Kriss A, Muller DPR (1999): Comparison of effects of four anesthetic agents on somatosensory evoked potentials in the rat. Laboratory Animals, 33: 243251.

7. Hoerlein BF (1965): Canine Neurology, Diagnosis and Treatment, 1965; 7-23. Philadelphia W.B. Saunders.

8. Holliday TA, Weldon NE, Ealand BG (1979): Percutaneus recording of evoked spinal cord potentials of dogs. American Journal of Veterinary Research, 40: 326333

9. Holliday TA (2003): Volume conduction principles in clinical neurophysiology. Part C. Veterinary Neurology and Neurosurgery, Published online at http://www.neurovet.org/Electrophysiology/VolumeCondu ction.

10. Jou IM (2000): Effectsof Core Body temperature on Changes in Spinal Somatosensory - Evoked Potential in Acute SpinalCord Compression Injury: An Experimetal Study in the Rats. Spine25, 15,1878-1885.

11. Kim NH, Yang IH, Song IK (1994): Electrodiagnostic and histologic changes of graded caudal compression on cauda equina in dog. Spine 1994; 19: 1054-1062.

12. Laschinger JC, Cunningham JN, Baumann FG (1987): Monitoring of somatosensory evoked potentials during surgical procedures on the thoracoabdominal aorta. Journal of Thoracic and Cardiovascular Surgery, 1987; 9: 260-265.

13. Nordwall A, Axelgaard J, Harada Y (1979): Spinal cord monitoring using evoked potentials recorded from feline vertebral bone. Spine, 1979; 4:486-494

14. Poncelet L (1999): Electrophysiological assessment of spinal cord function through somatosensory evoked potentials in dogs. Veterinary Neurology and Neurosurgery Web site, Published online at:http://www.vin.com/NN/Journal.plx? ID=1471082.

15. Poncelet L, Michaux CH, Balligand M (1998): Somatosensory potentials in dogs suffering naturallyacquired thoracolumbar spinal cord compression. American Journal of Veterinary Research, 59: 300-306.

16. Poncelet L, Michaux CH, Balligand M (1993): Effect of body size on tibial somatosensory evoked potentials in dogs. American Journal of Veterinary Research, 54: 178182.
17. Powers SK, Bolger CA, Edwards MSB (1982): Spinal cord pathways mediating somatosensory evoked potentials. Journal of Neurosurgery, 75: 472-482.

18. Redding RW, Lee AH, Wilson SG (1984): Spinal evoked potentials and spinal conduction velocity of the cat: Reference values. American Journal of Veterinary Research, 45: 2175-2177.

19. Sande RD (1992): Radiography, myelography, computed tomography and magnetic resonance imaging of the spine. The Veterinary Clinics of North America, Small Animal Practice, 22: 811-831.

20. Sarnowsky RJ, Cracco RQ, Vogel HB, Mount F (1975): Spinal evoked response in the cat. Journal of Neurosurgery, 43:329-336.

21. Schramm J, Krause R, Shigeno T, Brock M (1983): Experimental investigation on the spinal cord evoked injury potential. Journal of Neurosurgery, 59: 485-492.

22. Sharma HS, Winkler T (2002): Assessment of spinal Cord Pathology Following Trauma Using Early Changes in the Spinal Cord Evoked Potentials: A pharmacological and Morphological Study in the Rat. Spinal Cord Pathology, 11; 83-91.

23. Sharma HS, Winkler T, Stalberg E, Olsson Y, Dey PK (1991): Evaluation of Traumatic Spinal Cord Edema Using Evoked Potentials Recorded from the Spinal Epidural Space. Journal of the Neurological Sciences, 102: 150-162.

24. Sims MH, Selcer RR (1989): Somatosensory-evoked and spinal cord-evoked potentials in response to pudendal and tibial nerve stimulation in cats. American Journal of Veterinary Research, 50: 542-545.

25. Steiss JE, Wright JC (1990): Maturation of spinal evoked potentials to tibial and ulnar nerve stimulation in clinically normal dogs. American Journal of Veterinary Research, 51: 1427.

26. Thompson SE, Moore MP, Lincoln JD (1990): Intraoperative monitoring of sciatic nerve function with somatosensory evoked potentials. Veterinary Surgery, 19: 276-282.

27. Wheeler SJ, Sharp NJH (1994): Small Animal Spinal Disorders Diagnosis and Surgery, 31 - 55, Mosby.

28. Zileli M, Taniguchi M, Cedzich C, Schramm J (1989): Vestibulospinal Evoked Potentials versus Motor Evoked Potentials Monitoring in Experimental Spinal Cord Injuries of Cats. Acta Neurochirurgica, 101: 141-146.

Geliş tarihi: 21.10.2010 / Kabul tarihi: 07.04.2011
Address for correspondence:
Oytun Okan Şenel, DVM, PhD
Department of Surgery
Faculty of Veterinary Medicine
Ankara University, 06110, Ankara, TURKEY
E-mail: osenel@veterinary.ankara.edu.tr 